\title{
Cyanobacteria and microcystins occurrence in the Guadiana River (SW Spain)
}

\author{
ISABEL MORENO†, GUILLERMO REPETTO†, ESTHER CARBALLAL \\ ANA GAGO \\ $\dagger$ †Área de Toxicología, Facultad de Farmacia, Universidad de Sevilla, \\ C/Profesor García González s/n, 41012-Sevilla, Spain \\ †Departamento de Química Analítica y Alimentaria, Facultad de Ciencias, \\ Universidad de Vigo, Marcosende, 36200-Vigo, Spain
}

(Received 22 October 2004; in final form 29 March 2005)

\begin{abstract}
This work reports on the survey carried out to determine the presence of microcystins (MCs) by using ELISA tests and HPLC-UV for such determination in different sample sites along the Spanish course of the Guadiana River. The most important cyanobacteria species identified were, Microcystis aeruginosa and Oscillatoria spp. The highest total microcystin content recorded was $6.40 \mu \mathrm{g} \mathrm{L}^{-1}$ in 2002. The main toxins found were microcystins RR and LR, with microcystin YR present at trace levels. Improvements in sample clean up were carried out by using Immunoaffinity solid phase extraction (SPE) and its advantages regarding to conventional SPE were clearly demonstrated. The confirmation of MCs presence in the evaluated water reservoirs, underlines the necessity of monitoring programs as well as the improvement of analytical methodologies to efficiently prevent the human health risks as a consequence of MCs contamination.
\end{abstract}

Keywords: Guadiana River; Cyanobacteria; Microcystins; ELISA; HPLC-UV; IAC

\section{Introduction}

Toxic blooms of cyanobacteria in freshwaters have been reported in many water bodies throughout the world [1-6], being a clear sign of eutrophication, which has become more intensive during the last century [7]. Anthropogenic inputs by domestic, industrial, agricultural and urban discharges have been identified as the primary cause for this enrichment [8]. Surveys in different parts of the world have revealed that between $25 \%$ and $75 \%$ of cyanobacterial blooms are toxic [9]. The main toxic cyanobacteria genera include: Microcystis, Anabaena, Nostoc, Oscillatoria and Aphanizomenon [2, 10, 11]. Cyanobacterial toxins fall into four classes: hepatotoxins, neurotoxins, non-specific toxins and lipopolysaccharides. Hepatotoxins are the most commonly encountered [12].

\footnotetext{
*Corresponding author. Fax: +34-95-4233765. Email: camean@us.es
} 
Microcystins (MCs) are a group of cyclic peptide hepatotoxins that might be produced by freshwater cyanobacteria and currently more than 70 structural homologues, with a cosmopolitan distribution, are known [13]. The chemical structures of the hepatotoxins are composed of five common amino acids with variations that combine a pair of L-amino acids. The structural differences among the toxins are related to the two L-amino acids; also desmethyl derivatives have been reported in which methyl groups of $\mathrm{N}$-methyl aspartic acid are replaced by hydrogen atoms [14].

These toxins have caused massive mortality among wild and domestic animals [15] and also constitute a hazard to human health, particularly by ingestion, and skin irritation and even death of humans exposed to microcystins during haemodialysis [16]. Microcystins have mainly hepatotoxic activity in humans [17], although they produce gastrointestinal alterations [18], allergic reactions or irritation [2], and symptoms like pneumonia [19]. At a biochemical level the toxic mechanism of MCs is based on the inhibition of protein phosphatases 1 and 2A of eukaryotic cells [20]. Furthermore, some studies describe MCs as potent tumour promoter [21]; the possibility of carcinogenesis and also their genotoxic activity [22] has also been considered. Some epidemiological data reported in the literature about MCs contaminations in drinking waters, indicate that these toxins are responsible for the high incidences of primary liver cancer (PLC) in China among drinkers of pond and ditch water [23, 24].

These potential health hazards and the worldwide occurrence of MCs justify regular monitoring of drinking and recreational waters. Some surveys have demonstrated the toxicity of water blooms in several areas of Portugal, including the Douro River and the Guadiana River [2, 10, 11, 25-27].

The Guadiana River is a mesotidal fluvial-marine system located on the southwestern Iberian Peninsula, is the fourth largest drainage basin of Iberian rivers $\left(67,840 \mathrm{~km}^{2}\right)$. The total river length is $810 \mathrm{~km}$, of which $550 \mathrm{~km}$ is in Spanish territory and $180 \mathrm{~km}$ in Portuguese area. The phytoplankton community in the Guadiana estuary, located between Portugal and Spain, was previously characterized by Rocha et al. [28] who reported an increasing occurrence of summer cyanobacteria blooms dominated by the potentially toxic Microcystis spp. The concentration of toxins varies not only for different strains of cyanobacteria, but also for different clones of the same isolate [29]. In previous works, the phytoplankton community was characterized at several locations along the Guadiana River through the Spanish area and the predominance of some Cyanophyceae, such as Microcystis aeruginosa, Anabaena spp., Oscillatoria spp. and Aphanizomenon flos-aquae was reported [30, 31].

Different methods have been applied for the analysis of MCs including inhibition of protein phosphatases 1 and 2A [32, 33], ELISA immunoassay, based on molecular recognition by certain antibodies which have good cross-reactivity with microcystinLR (MC-LR), microcystin-RR and microcystin-YR, but less reactivity with variants microcystin-LY and microcystin-LA [3, 24, 34], high-performance liquid chromatography (HPLC) with UV or mass spectrometric detection (MS) [35, 36] and high-performance capillary electrophoresis (HPCE) [37, 38]. Each of these methods provides different information on the MCs content of unknown samples. The first two approaches measure total MCs relative to a single microcystins standard, usually microcystin-LR, and do not provide any information on the actual MCs composition in the samples [39]. Moreover, in the ELISA technique the antibody M8H5 reacts to the non-toxic monomethyl ester of MC-LR giving a false positive from the toxicological point of view [3], and several physicochemical variables (salinity, $\mathrm{pH}$, etc.) can produce 
false positive MCs results [40]. HPLC and HPCE methods can be much more definitive since they provide structural information for the identification of these hepatotoxins. In the present study, water reservoirs along the course of the Guadiana River, between Mérida and Badajoz (Spain), were surveyed to study the occurrence of cyanobacteria biomass and the corresponding MCs levels over three consecutive years (2001-2003). We conducted this study using different preparation techniques to determine MCs in water samples from the Guadiana River, destined for different purposes (swimming and recreation activities), by ELISA and HPLC-UV, including sample clean-up with anti-microcystin-LR immunoaffinity cartridges.

\section{Experimental}

\subsection{Chemicals and standards}

All chemicals and reagents were of analytical grade. Distilled, deionized water (Milli-Q Water Systems, Millipore Corporation, Bedford, MA, USA) was used throughout. Standards of microcystins MC-LR, MC-RR and MC-YR were purchased from Calbiochem-Novabiochem (Nottingham, UK). Standard solutions were prepared in methanol $\left(500 \mu \mathrm{g} \mathrm{mL}^{-1}\right)$ and were diluted as required with water Milli-Q for use as working solutions. Phosphate buffered saline (PBS) was prepared by dissolving $1.63 \mathrm{~g}$ $\mathrm{Na}_{2} \mathrm{HPO}_{4}, 0.50 \mathrm{~g} \mathrm{NaH}_{2} \mathrm{PO}_{4}$ and $4.09 \mathrm{~g} \mathrm{NaCl}$ in $500 \mathrm{~mL}$ of water. The $\mathrm{pH}$ was adjusted to $\mathrm{pH} 7.4$ with $1 \mathrm{M} \mathrm{NaOH}$.

\subsection{Collection of samples}

Water samples amounting to $3 \mathrm{~L}$ were taken in the period May-October 2001-2003, from the surface near the shore of the Guadiana River, between Mérida and Badajoz (Spain). The local sampling sites were four locations along the river (Vitonogales, Valdelacalzada, Barbaño, and Pescadores) and two water bodies used principally for irrigation, recreational purposes and as drinking water supplies (Montijo and Alange reservoirs). These sampling sites are shown in figure 1. Field campaigns started in May 2001 as part of a preliminary study, and extended weekly (or every two weeks) to October 2001 and 2002-2003. Of the 98 samples obtained, 22 were taken in 2001, 48 in 2002 and 28 in 2003.

The samples were stored and transported to the laboratory in ice chests. Subsamples $(100 \mathrm{~mL})$ were preserved in lugol solution and observed with an inverted microscope using 5-10 mL sedimentation chambers for phytoplankton identification and cyanobacteria quantification [41]. Subsamples $(500 \mathrm{~mL})$ were filtered under low pressure in the dark to avoid photodegradation of pigments, for chlorophyll $a$ determination through glass microfiber Whatman GF/C filters (Whatman, Maidstone, UK). The pigments were extracted from the plankton concentrate with $100 \%$ methanol $(10 \mathrm{~mL})$ at $4{ }^{\circ} \mathrm{C}$ for $24 \mathrm{~h}$ and were determined according to the American Public Health Association method [42]. The optical density (absorbance) of the extracts was measured at $665 \mathrm{~nm}$ and $725 \mathrm{~nm}$ with a spectrophotometer (Hitachi, model U-2001, Tokyo, Japan).

\subsection{MCs analysis by ELISA assay}

Enzyme-linked immunosorbent assay (ELISA) was used for direct determination of total MCs in natural water samples from the Guadiana River (Envirogard ${ }^{\circledR}$, Strategic 


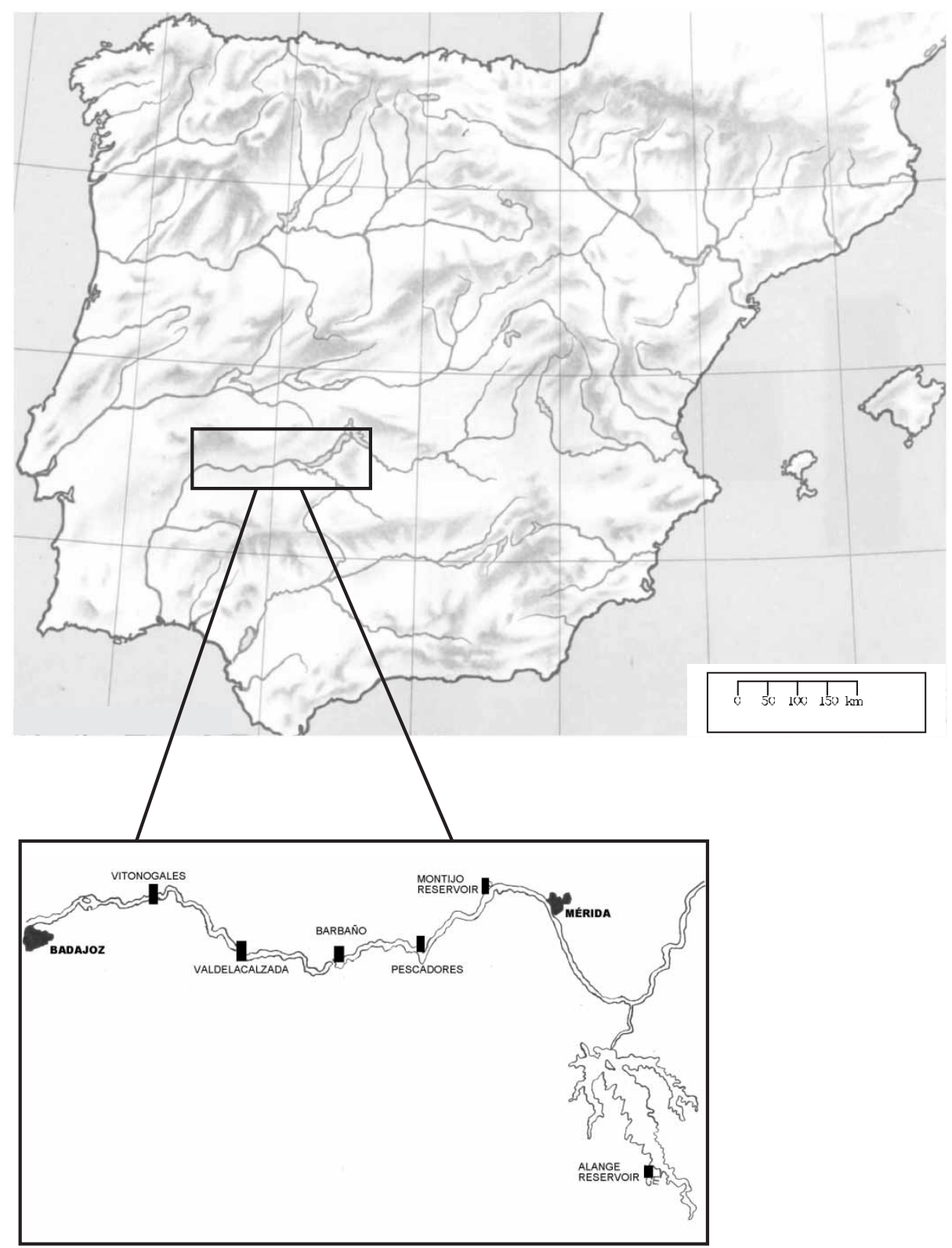

Figure 1. Map of the Guadiana River and surrounded area, showing locations where samples were collected, from Vitonogales point to the Alange reservoir.

Diagnostic INC, Newark, USA). Approximately 5-10 mL aliquots of the water samples were packed in plastic tubes and capped. The tubes were subsequently kept frozen at $-20^{\circ} \mathrm{C}$ until analysis. Samples were subjected to ultrasonication to break cells and then filtered through a non-sterile $0.45 \mu \mathrm{m}$ filter (Millex HV13, Millipore, USA) before using these extracts for the test. The commercial ELISA kit used polyclonal antibodies and profited from the high cross-reactivity with a non-toxic microcystin variant 
and used it as a standard provided to calibrate the kit. Standard curves were established using different concentrations of the non-toxic calibrator, at levels equivalent to $0.1,0.4$ and $1.6 \mu \mathrm{g} \mathrm{L}^{-1} \mathrm{MC}-\mathrm{LR}$. Absorbance was measured at $450 \mathrm{~nm}$ with a microtiter plate reader (Titertek Multiskan Plus MK II, Westshore Technologies, Inc. Muskegon, USA). Results were obtained using a semilog curve fit for the standard curve and were expressed as microcystin-LR equivalents (MC-LR equiv.). The detection limit of microcystins in this assay was $0.1 \mu \mathrm{g} \mathrm{MC}-\mathrm{LR} / \mathrm{L}$.

\subsection{Extraction of MCs and clean-up of raw extracts}

Water subsamples (2L) were filtered through glass microfiber Whatman GF/C filters (Whatman, Maidstone, UK). The residue on filter paper was extracted according to the method of Lawrence and Menard [39]: the filters were extracted with a mixture of $20 \mathrm{~mL}$ methanol/water $(75 / 25)$ and the suspension was sonicated in an ultrasonic bath (Bransonic 32, Raypa, Barcelona, Spain) for $15 \mathrm{~min}$, stirred for $30 \mathrm{~min}$ at room temperature, and then centrifuged $(20 \mathrm{~min}$ ) at $4000 \mathrm{rpm}$ (Orto Alresa, model Digicen, Madrid, Spain). The residue was re-extracted with $10 \mathrm{~mL}$ of the mixture methanol/ water in the same way. The upper phases were combined and concentrated in a rotary evaporator (RV 05-ST, IKA ${ }^{\circledR}$ WERKE, Staufen, Germany). The residue was resuspended in methanol $(200-500 \mu \mathrm{L})$. The raw extracts were cleaned up using conventional solid-phase extraction (SPE) and immunoaffinity SPE procedures (IAC SPE). Conventional SPE was carried out following the conditions described by Aguete et al. [38]. After conditioning a $\mathrm{C}_{18}$ cartridge (Sep-Pak ${ }^{\circledR}$ PLUS $\mathrm{C}_{18}$ cartridges, $1 \mathrm{~g}$, Waters Corporation, Milford, USA) with methanol containing $0.1 \%$ trifluoroacetic acid (TFA) $(5 \mathrm{~mL})$, methanol $(5 \mathrm{~mL})$ and water $(5 \mathrm{~mL})$, the extract $(200-500 \mu \mathrm{L})$ was transferred to the cartridge. The cartridge was washed twice with $10 \mathrm{~mL}$ of water and the MCs were eluted with methanol-TFA $0.1 \%(5 \mathrm{~mL})$. The eluate was evaporated to dryness, the residue was dissolved in methanol $(100-500 \mu \mathrm{L})$ and the solution was used for the HPLC-UV analysis.

IAC SPE was performed using immunoaffinity cartridges (ImmunoSep $^{\mathrm{TM}}$, ImmunoKem Ltd., Canada) according to the conditions described by Lawrence and Menard [39], and Aguete et al. [38]. Cartridges were conditioned with water $(3 \mathrm{~mL})$ and $3 \mathrm{~mL}$ PBS prior to loading the sample $(200 \mu \mathrm{L})$. The cartridge was rinsed with $3 \mathrm{~mL}$ of PBS followed by $3 \mathrm{~mL}$ of water and then $3 \mathrm{~mL}$ of methanol/water $(25 / 75 \mathrm{v} / \mathrm{v})$. MCs were eluted with $6 \mathrm{~mL}$ methanol/water $(80 / 20 \mathrm{v} / \mathrm{v})$ containing $4 \%$ $(\mathrm{v} / \mathrm{v})$ acetic acid. The extract was rotary-evaporated to dryness and the residue was resuspended to a final volume of $100-500 \mu \mathrm{L}$ of methanol which were used for the HPLC-UV analysis.

\subsection{HPLC-UV determination of microcystins}

HPLC-UV analysis were performed according to the method described by Aguete et al. [37], using an LC-9012 pump, and a 9050 UV-Visible spectrophotometric detector (all from Varian, Walnut Creek, USA). Chromatographic data were processed with Star Chromatography Workstation software (version 4.5 Varian Associates Inc, Walnut Creek, USA). Separation was accomplished under reversed-phase isocratic conditions with a LiChrospher ${ }^{\circledR} 100 \mathrm{C}_{18}$ column $(250 \times 4 \mathrm{~mm})$ (Merck, Darmstadt, Germany). The mobile phase was $40 \%$ acetronitrile in water with $0.05 \%$ TFA as acidic 
organic modifier. The wavelength was set at $238 \mathrm{~nm}$ and the flow rate was $1 \mathrm{~mL} \mathrm{~min}{ }^{-1}$. Sample injection volumes were typically $20 \mu \mathrm{L}$. Retention times were approximately $12.8 \mathrm{~min}$ for microcystin RR, $15.7 \mathrm{~min}$ for YR and 16.4 for LR.

\section{Results}

\subsection{Incidence of cyanobacteria species and changes in chlorophyll a concentration}

The monitoring data concerning to the cyanobacterial biomass (no cell $\mathrm{mL}^{-1}$ ), chlorophyll $a$ concentration, and fluctuations of dominant species obtained in the Guadiana River from May to October 2001-2003 are shown in table 1. In general, the most

Table 1. Cyanobacteria species abundance along the Guadiana River in 2001-2003.

\begin{tabular}{|c|c|c|c|c|c|}
\hline & Description & $\begin{array}{c}\text { Total } \\
\text { samples }\end{array}$ & $\begin{array}{l}\text { Chlorophyll } a \\
\qquad\left(\mu \mathrm{g} \mathrm{L}^{-1}\right)\end{array}$ & $\begin{array}{l}\text { Cyanobacteria } \\
\text { quantification } \\
\mathrm{n}^{\circ} \text { cell } \mathrm{mL}^{-1}\end{array}$ & Species \\
\hline \multicolumn{6}{|c|}{ Sampling site 2001} \\
\hline Montijo & Reservoir & 6 & $15.8-257.3$ & NQ-9388 & Oscillatoria spp. ${ }^{\mathrm{b}}$, M. aeruginosa ${ }^{\mathrm{c}}$ \\
\hline Alange & Reservoir & - & - & - & - \\
\hline Pescadores & River & 5 & $12.5-273.1$ & NQ-2679 & Oscillatoria spp. ${ }^{\mathrm{a}}$, M. aeruginosa ${ }^{\mathrm{a}}$ \\
\hline Vitonogales & River & 5 & $14.9-268.7$ & $27,604-2,576,347$ & $\begin{array}{l}\text { Oscillatoria } \text { spp. }^{\mathrm{a}}, \text { A. } \text { circinalis }^{\mathrm{a}} \text {, } \\
\text { A. } \text { spiroides }^{\mathrm{a}}, \text { Aph. } \text { flos-aquae }^{\mathrm{b}}, \\
\text { M. } \text { aeruginosa }^{\mathrm{b}}, \text { A. }_{\text {inaequalis }}{ }^{\mathrm{c}}\end{array}$ \\
\hline Valdelacalzada & River & 6 & $20.7-232.1$ & $3574-900,434$ & $\begin{array}{l}\text { A. } \text { circinalis }^{\mathrm{a}}, \text { Oscillatoria spp. }{ }^{\mathrm{b}}, \\
\text { A. inaequalis }^{\mathrm{b}}, \text { M. aeruginosa }\end{array}$ \\
\hline Barbaño & River & - & - & - & - \\
\hline \multicolumn{6}{|c|}{ Sampling site 2002} \\
\hline Montijo & Reservoir & 9 & $10.5-108.2$ & $182-15,211$ & $\begin{array}{l}\text { M. aeruginosa }{ }^{\mathrm{a}}, \text { A. } \text { aphanizomenoides }^{\mathrm{a}} \text {, } \\
\text { A. } \text { inaequalis }^{\mathrm{a}}, \text { A. } \text { spiroides }^{\mathrm{a}}, \\
\text { Oscillatoria } \text { spp. }^{\mathrm{c}}\end{array}$ \\
\hline Alange & Reservoir & 7 & $0.8-21.9$ & $404-3483$ & $\begin{array}{l}\text { Oscillatoria spp. }{ }^{\mathrm{a}}, \text { A. solitaria } \\
\text { Aph. flos-aquae } \\
\text { a }, \text { M. aeruginosa }\end{array}$ \\
\hline Pescadores & River & 8 & $29.2-127.7$ & $335-10,905$ & $\begin{array}{l}\text { Aph. flos-aquae }{ }^{\mathrm{a}}, \text { Oscillatoria spp. }^{\mathrm{a}}, \\
\text { M. aeruginosa }{ }^{\mathrm{b}}, \text { A. aphanizomenoides } \\
\text { Aph. issatchenkoi }\end{array}$ \\
\hline Vitonogales & River & 8 & $117.6-320.0$ & $1089-32,404$ & $\begin{array}{l}\text { M. aeruginosa }{ }^{\mathrm{c}}, \text { Aph. flos-aquae } \\
{\text { A. } \text { circinalis }^{\mathrm{a}}}^{\mathrm{a}}\end{array}$ \\
\hline Valdelacalzada & River & 9 & $34.4-288.0$ & $1302-1,09,9817$ & $\begin{array}{l}\text { A. } \text { inaequalis }^{\mathrm{a}}, \text { A. } \text { spiroides }^{\mathrm{a}} \text {, } \\
\quad \text { M. aeruginosa }{ }^{\mathrm{b}} \text {, Oscillatoria } \text { spp. }^{\mathrm{c}}\end{array}$ \\
\hline Barbaño & River & 7 & $40.0-101.2$ & $55-35,532$ & $\begin{array}{l}\text { A. } \text { inaequalis }^{\mathrm{a}}, \text { M.aeruginosa }^{\mathrm{b}} \text {, } \\
\text { An. flos-aquae }^{\mathrm{b}} \text {, Oscillatoria spp. }{ }^{\mathrm{b}} \text {, } \\
\text { A. Issatchenkoi }^{\mathrm{b}}, \text { Aph. flos-aquae }\end{array}$ \\
\hline \multicolumn{6}{|c|}{ Sampling site 2003} \\
\hline Montijo & Reservoir & 7 & $2.9-20.9$ & $185-21,529$ & $\begin{array}{l}\text { An. flos-aquae }{ }^{\mathrm{a}}, \text { M. Aeruginosa }{ }^{\mathrm{b}} \text {, } \\
\text { Aph. Issatchenkoi }^{\mathrm{b}} \text {, Oscillatoria } \text { spp. }^{\mathrm{c}}\end{array}$ \\
\hline Alange & Reservoir & - & - & - & - \\
\hline Pescadores & River & 7 & $5.9-16.0$ & $1261-16,432$ & $\begin{array}{l}\text { M. aeruginosa }{ }^{\mathrm{b}}, \text { Aph }_{\text {issatchenkoi }}^{\mathrm{b}} \text {, } \\
\text { A. inaequalis }^{\mathrm{c}} \text {, Oscillatoria } \text { spp. }^{\mathrm{c}}\end{array}$ \\
\hline Vitonogales & River & 7 & $12.8-235.2$ & $856-3,63,222$ & M. aeruginosa ${ }^{\mathrm{c}}$, Aph. flos-aquae $e^{\mathrm{a}}$ \\
\hline Valdelacalzada & River & 7 & $9.1-402.4$ & $12,532-16,449,964$ & $\begin{array}{l}\text { M. aeruginosa }{ }^{\mathrm{c}}, \text { Aph. flos-aquae }^{\mathrm{a}} \text {, } \\
\text { A. inaequalis }^{\mathrm{a}}\end{array}$ \\
\hline Barbaño & River & - & - & - & - \\
\hline
\end{tabular}

${ }^{\mathrm{a}}$ Present. ${ }^{\mathrm{b}}$ Subdominant. ${ }^{\mathrm{c}}$ Dominant. $\mathrm{NQ}$, not quantified. 
frequent cyanobacterial species in the Guadiana River were M. aeruginosa, Oscillatoria spp., and some species of Aphanizomenon (Aph. flos-aquae and Aph. issatchenkoi). Anabaena inaequalis and $A$. spiroides were also found to be dominant in some of the samples from this region. The highest levels of cyanobacteria along the period of this evaluation were recorded in Valdelacalzada and Vitonogales. The maximum cyanobacteria cell density $\left(16,449,964\right.$ cells $\left.\mathrm{mL}^{-1}\right)$ was reached in Valdelacalzada in summer 2003 , one of the warmest years in recent decades.

Chlorophyll $a$ concentrations differed among reservoirs studied along the monitoring period. In 2001, the values of chlorophyll $a$ varied within a range of $12.5-273.1 \mu \mathrm{g} \mathrm{L}^{-1}$. In the years 2002-2003 the ranges of this parameter were higher and the maximum concentration was recorded at $402.4 \mu \mathrm{g} \mathrm{L}^{-1}$ in Valdelacalzada on June 2003, concomitant with the cyanobacterial density peak mentioned above. The maximum peaks of chlorophyll $a$ were found in Vitonogales and Valdelacalzada, coinciding with maximum densities of cyanobacterial biomass in the last location, although the maximum in 2002 at Vitonogales occurred at much lower cyanobaterial cell densities.

\subsection{Microcystins in natural samples}

A specific ELISA test for total MCs was used to evaluate the MCs present in water samples collected from the different points along the Guadiana River during the monitoring period. The results revealed the presence of MCs in different levels over the years studied, as it can be observed in the ranges of values reported in table 2 . The highest value $\left(19.00 \mu \mathrm{g} \mathrm{L}^{-1}\right.$ MC-LR equivalent) was found in Valdelacalzada in

Table 2. MCs contents obtained by ELISA assay and HPLC analysis from the six sampling sites in 2001, 2002 and 2003.

\begin{tabular}{|c|c|c|c|c|c|}
\hline & \multirow{2}{*}{$\begin{array}{c}\text { ELISA } \\
\mu \mathrm{g} \text { MC-LR equiv/L }\end{array}$} & \multicolumn{3}{|c|}{ MCs content $\left(\mu \mathrm{g} \mathrm{L}^{-1}\right)$} & \multirow{2}{*}{$\begin{array}{c}\text { MCs total } \\
\text { content }\left(\mu \mathrm{gL}^{-1}\right)\end{array}$} \\
\hline & & MC-RR & MC-YR & MC-LR & \\
\hline \multicolumn{6}{|l|}{ Sampling site 2001} \\
\hline Montijo & ND-0.17 & ND & ND & ND & ND \\
\hline Alange & - & - & - & - & - \\
\hline Pescadores & ND & ND & ND & ND & ND \\
\hline Vitonogales & $0.14-2.8$ & NQ- 0.24 & ND & ND- 0.55 & ND-0.79 \\
\hline Valdelacalzada & $0.12-3.3$ & ND & ND & NQ -0.17 & ND -0.17 \\
\hline Barbaño & - & - & - & - & - \\
\hline \multicolumn{6}{|l|}{ Sampling site 2002} \\
\hline Montijo & $0.11-0.80$ & ND-NQ & ND-NQ & ND- 0.11 & ND-0.11 \\
\hline Alange & ND-0.31 & ND-NQ & ND-NQ & ND-NQ & ND \\
\hline Pescadores & $0.10-0.20$ & ND & ND & ND & ND \\
\hline Vitonogales & $0.10-2.90$ & ND-1.29 & ND-NQ & ND -0.25 & ND-1.54 \\
\hline Valdelacalzada & $0.10-10.50$ & ND-0.62 & ND -0.18 & ND-5.6 & ND-6.4 \\
\hline Barbaño & $0.10-0.62$ & ND -0.14 & ND-NQ & NQ- 0.22 & ND -0.36 \\
\hline \multicolumn{6}{|l|}{ Sampling site 2003} \\
\hline Montijo & ND -0.43 & ND-NQ & ND & ND-NQ & ND \\
\hline Alange & - & - & - & - & - \\
\hline Pescadores & ND-0.13 & ND & ND & ND & ND \\
\hline Vitonogales & $0.12-9.30$ & ND-1.05 & ND -0.19 & ND -0.31 & ND-1.55 \\
\hline Valdelacalzada & $0.19-19.00$ & ND-1.35 & ND -0.35 & $0.10-0.72$ & ND-2.57 \\
\hline Barbaño & - & - & - & - & - \\
\hline
\end{tabular}

ND, not detected. NQ, not quantified. 


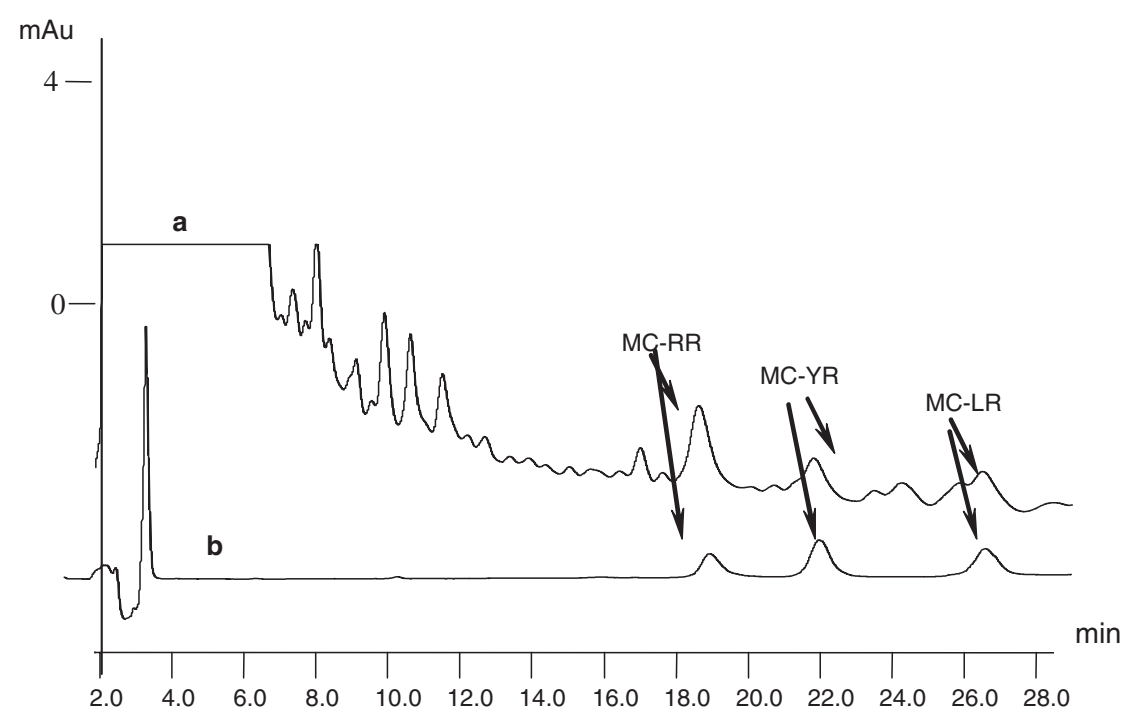

Figure 2. Analysis of (a) an algae extract (Valdelacalzada, June 2003) after SPE $\mathrm{C}_{18}$ clean-up and (b) a standard of the three toxins $\left(5 \mathrm{mg} \mathrm{L}^{-1}\right)$.

2003. Previously, in 2001 and 2002, the maximum total MCs amounts in this location were 3.3 and $10.5 \mu \mathrm{g}$ MC-LR equiv/L, respectively. In Vitonogales total MCs were also usually detected (maximum concentration of $9.3 \mu \mathrm{g} \mathrm{L}^{-1}$ MC-LR equivalent in 2003).

HPLC analysis was carried out after a conventional SPE clean-up of the evaluated extracts and the results obtained showed the presence of several MCs in samples from the Guadiana River collected during 2001-2003. The common MCs encountered were MC-RR, MC-LR and MC-YR as it is shown in figure 2.

SPE using immunoaffinity was also applied for the clean-up of some water samples (see figure 3). Figure 3(a) shows the chromatogram obtained for the HPLC analysis of a water sample after SPE extraction. A major unknown peak is observed and two peaks with retention times corresponding to MC-RR and MC-LR standards were obtained as well as several co-eluting peaks. The presence of MC-RR, MC-LR and an unknown compound were observed in figure $3(\mathrm{~b})$, however, the other interference peaks were effectively removed following the immunoaffinity clean-up. These results show the effectiveness of IAC for removing interferences resulting in cleaner chromatograms therefore contributing to an increased sensitivity. The presence of the unidentified peak could be associated with a MC analogue whose identity has not been confirmed due to the unavailability of standards. Nevertheless, the use of IAC clean up and the knowledge about the ability of the antibodies used to recognize a wide range of MCs could be considered as a good basis for such confirmation; further experiments by using MCs detection should be carried out to confirm this hypothesis.

The results obtained for the HPLC analysis of waters from Montijo, Valdelacalzada and Vitonogales showed similar toxin profiles with MC-RR and MC-LR frequently observed (figure 4). Moreover, a small amount of MC-YR was occasionally detected in some samples from Valdelacalzada and Vitonogales.

The concentration of MC-RR in the samples tested ranged between ND-1.35 $\mu \mathrm{g} \mathrm{L}^{-1}$, the level of MC-LR concentration ranged between ND-5.6 $\mu \mathrm{g} \mathrm{L}^{-1}$, and the amounts 

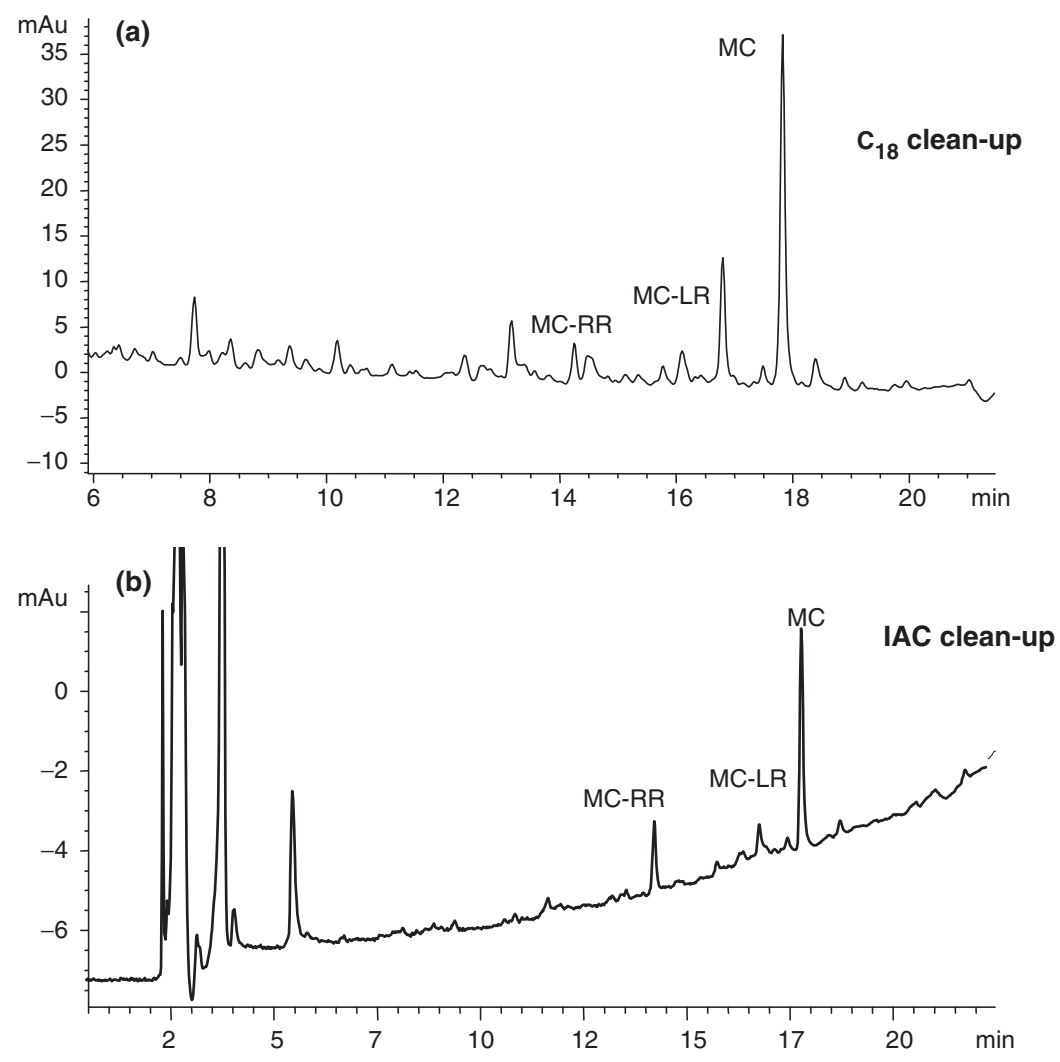

Figure 3. Comparison of different clean-up procedures for a water sample naturally contaminated (Valdelacalzada, June 2002) with MC-RR, MC-LR and one microcystin not identified. (a) SPE clean-up and (b) IAC clean-up employed.

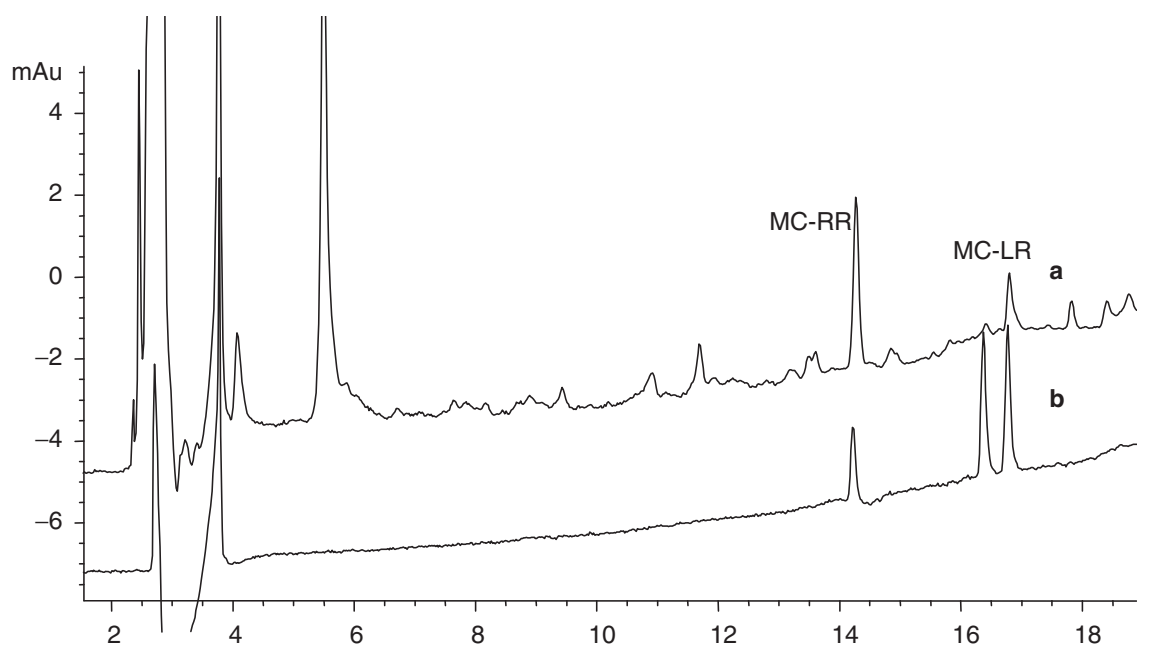

Figure 4. Analysis of (a) an algae extract (Vitonogales, August 2002) and (b) a standard of the three toxins $\left(1 \mathrm{mg} \mathrm{L}^{-1}\right)$. 
of MC-YR ranged between ND- $0.35 \mu \mathrm{g} \mathrm{L}^{-1}$ (table 2). The highest value $\left(6.40 \mu \mathrm{g} \mathrm{L}^{-1}\right.$ of total MCs) was determined in Valdelacalzada in 2002. HPLC analysis of MCs showed lower concentration values in comparison with the ones obtained through ELISA (table 2). Previous studies showed the poor correlation between HPLC and ELISA for these particular compounds.

\section{Discussion}

Different cyanobacterial species were present in the water samples from the Guadiana River evaluated in this study. The highest density was observed from Valdelacalzada and Vitonogales. M. aeruginosa and Oscillatoria spp. were the dominant species throughout the monitoring period. These results are in accordance with data found from other authors [4, 43-46], who had also shown that M. aeruginosa and Oscillatoria spp. were the predominant species in freshwater reservoirs throughout the world.

Preliminary results confirm the presence and distribution of cyanobacterial blooms in Portuguese freshwater with a predominance of Microcystis aeruginosa, MCs being the most common toxins produced for this specie [47]. Earlier studies carried out in the Guadiana River also demonstrated the dominance of cyanobacteria blooms in associations with high $\mathrm{N}$ and $\mathrm{P}$ levels; these cyanobacteria blooms were more frequent through the period from late spring to early summer and the predominant species were Microcystis spp. [28, 47]. Moreover, in a previous work, broad and sudden variations in the phytoplankton density along the Spanish course of the Guadiana River, depending on the spatial distribution of the sampling sites, were demonstrated [31].

Chlorophyll $a$ is a widely used and accepted measure of biomass [43, 46, 48, 49] when the phytoplankton chiefly consists of cyanobacteria. In our study, the measure of the chlorophyll $a$ was carried out in order to observe the correlation between this parameter and the biomass quantified by microscopic estimations.

According to the Organization for Economic Cooperation and Development (OECD) guidelines [50], $8 \mu \mathrm{g}$ of chlorophyll/L is considered the boundary between mesotrophy and eutrophy. Also, according to Bartram et al. [51] peak values of chorophyll $a$ for an oligotrophic lake are about $1-10 \mu \mathrm{gL}^{-1}$, while in a eutrophic lake they can reach $300 \mu \mathrm{g} \mathrm{L}^{-1}$. The chlorophyll $a$ concentrations in the samples collected from Alange reservoir were lower than $8 \mu \mathrm{g} \mathrm{L}^{-1}$, except for one sample $\left(21.9 \mu \mathrm{g} \mathrm{L}^{-1}\right.$ in 2002). In Montijo reservoir, used for human consumption, there was variability in the chlorophyll $a$ values obtained, especially in 2001, with a total range between $2.9 \mu \mathrm{g} \mathrm{L}^{-1}$ in 2003 to $257.3 \mu \mathrm{g} \mathrm{L}^{-1}$ in 2001 . This fact could be explained because of the water supplies in this reservoir vary regularly, depending on run-off levels and human necessities. Concerning water used for swimming, agriculture and fishing activities (the other four locations) it would be appear that these points are in eutrophic state and this phenomenon is severe in summer and early autumn.

These variations in chlorophyll $a$ levels along the monitoring period and among different sample points are coincident with the results reported by others authors around the world $[43,45,46,52]$. Rises in chlorophyll $a$ can be explained depending on the higher nutrient availability and decreases can be explained as a result of oligotrophic water predominance [46].

It could be said that all the samples appeared to show a correlation between quantification results and chlorophyll $a$ values, mainly in Vitonogales and Valdelacalzada 
sample points, where the maximum cellular density $\left(2,576,347\right.$ cells $\mathrm{mL}^{-1}$ and $16,449,964$ cells $\mathrm{mL}^{-1}$, respectively) were concomitant with an increase in chlorophyll $a$ values $\left(268.7 \mu \mathrm{g} \mathrm{L}^{-1}\right.$ and $402.43 \mu \mathrm{g} \mathrm{L}^{-1}$ respectively). Therefore, it can be concluded that the chlorophyll $a$ concentration in some water reservoirs in the Guadiana River is mainly determined by the number of cyanobacteria in the phytoplankton.

The potential toxicity of the predominant species detected in the natural waters studied (M. aeruginosa, Oscillatoria spp.) had been previously documented [2, 10, 12, 53]. For this reason it is wise to consider all samples collected from water reservoirs as toxic and confirm the presence of toxins using ELISA assay as a preliminary screening and subsequent confirmation by HPLC analysis.

The total MCs concentration detected by ELISA assay as a preliminary test in natural waters from only two locations, Valdelacalzada and Vitonogales, were higher than the level that would cause concern for human and animal health. It should be stressed that the World Health Organization (WHO) referenced $1 \mu \mathrm{g} \mathrm{L}^{-1}$ as a provisional guideline value for microcystins in drinking water [3]. This level was exceeded each year of the monitoring period in both points. The presence of MCs above the WHO guideline level was detected with a frequency of $36 \%$ (Valdelacalzada) and $38 \%$ (Vitonogales) of the samples tested. Based on these results the basic water quality must be routinely examined to provide information on it. In the rest of the sample sites the concentration of total MCs did not exceed the maximum level recommended by WHO.

The MCs levels have been correlated with phytoplankton density and chlorophyll $a$ concentration [54]. Similar results were obtained in our work, with seasonal changes in the total MCs concentration, positively correlated to the abundance and biomass of $M$. aeruginosa and chlorophyll $a$ in Valdelacalzada and Vitonogales (tables 1 and 2).

SPE has been widely used for extraction and preconcentration procedures, resulting in poor selectivity for trace analysis. Recently, IAC have been developed for these applications, showing clear advantages for sample preparation [38]. In this work the application of both techniques for clean-up purposes was effective in isolating MCs from water samples (figures 2 and 3). A comparison of figure 3(a) and (b) shows the advantage of the application of IAC for clean-up prior to HPLC-UV determination. The extracts resulting of the IAC clean-up were cleaner than those obtained by conventional SPE. The efficiency of the IAC contributed to enhance the sensitivity of HPLCUV for the analysis of MCs in naturally contaminated water samples and demonstrates the great selectivity of IAC for samples clean-up at very low concentration level. This result is congruent with those obtained by Lawrence and Menard [39], Kondo et al. [55] and Aguete et al. [38] who reported the potential application of IAC to lyophilized cyanobacterial cells and water samples.

The main toxins detected by HPLC-UV in the tested samples were MC-RR and MC-LR (see figure 4 and table 2); MC-YR was present as a trace component (figure 4a). Although MC-LR is the most common microcystin reported in the literature, the major microcystins found have varied between different studied cyanobacterial species and populations, and also between different geographic regions [56].

In our work, maximum concentration of MC-LR found, $5.6 \mu \mathrm{g} \mathrm{L}^{-1}$, in Valdelacalzada 2002, was similar to those reported by Lahti et al. [57] $\left(0.01-7.40 \mu \mathrm{g} \mathrm{L}^{-1}\right)$ and lower than those reported by Park et al. [58] $\left(0.1-20.4 \mu \mathrm{g} \mathrm{L}^{-1}\right)$ and Oh et al. [54] $\left(0.4-21.6 \mu \mathrm{g} \mathrm{L}^{-1}\right)$. Similarly, MC-RR predominated in Valdelacalzada, in 2003, with a maximum of $1.35 \mu \mathrm{g} \mathrm{L}^{-1}$ and in the other eutrophic reservoir, Vitonogales $\left(1.29 \mu \mathrm{g} \mathrm{L}^{-1}\right.$ in 2002 and 
$1.05 \mu \mathrm{g} \mathrm{L}^{-1}$ in 2003). These values were comparable to those reported by Park et al. [58] for Suwa Lake in Japan $\left(0.1-30.1 \mu \mathrm{g} \mathrm{L}^{-1} \mathrm{MC}-\mathrm{RR}\right)$. In addition, only trace amounts of MCs were quantified in Montijo $\left(0.11 \mu \mathrm{g} \mathrm{L}^{-1}\right.$ MC-LR in 2002) and in Barbaño $\left(0.14 \mu \mathrm{g} \mathrm{L}^{-1}\right.$ MC-RR, $0.22 \mu \mathrm{g} \mathrm{L}^{-1}$ MC-LR in 2002). Peaks in microcystin contents were recorded during mid-summer periods, when high irradiance and stable water columns favour the growth of cyanobacteria which is in agreement with Jungmann and Benndorf [59].

Domination of MC-LR, MC-RR and MC-YR in cyanobacterial bloom samples has been described in waterbodies from central part of Europe, but in many German waterbodies, dm-MC-LR and dm-MC-RR were also produced [60]. Desmethyl derivatives have also been reported in Japanese freshwater sources [1], in which methyl groups of $\mathrm{N}$-methyldehydroalanine and $\mathrm{N}$-methyl aspartic acid were replaced by hydrogen atoms. The occurrence of MC-LR has been reported in Portugal since 1990 and a significant number of water reservoirs which are used for drinking water have been reported to have high levels of this toxin [27]. In several studies from Denmark and Slovakia it was shown that MC-LR was the main constituent microcystin in Microcystis blooms, sometimes accompanied by MC-RR, MC-YR or other MCs [61, 62].

Similarly, the main toxins produced by Microcystis in other countries were MC-RR and MC-LR, while the amount of MC-YR varied irregularly, being slightly detected or not al all [1, 14, 44, 45, 63, 64]; moreover, its isoform desmetil MC-YR is considered a secondary component or not detected. The fact that MC-YR appears in trace amounts in natural samples of water and in cyanobacterial blooms extracts was confirmed in cultures assays with different strains of Microcystis viridis [65]. In contrast, Finnish Microcystis blooms contained mainly desmethylated variants of MC-LR, MC-RR and MC-YR [66]. In central Spain, a demethylated variant of MC-RR was identified as the major microcystin in most samples [67]. These monodesmethyl and didesmethyl variants were also detected in cyanobacterial material from Polish freshwaters but they did not exceed $5 \%$ of total microcystin content [56].

Differences between the results obtained by HPLC-UV and ELISA techniques were observed in the present study with overestimated levels detected in the later one. This might be due to the non-specificity of the ELISA assay mainly when the amounts of MCs detected are near to its detection limit $\left(0.1 \mu \mathrm{g} \mathrm{L}^{-1}\right)$. Similarly, the comparison of LC/MS, ELISA and phosphatase assay for the determination of MCs in blue-green algae products, revealed that the LC-MS/MS results were significantly lower than biochemical assays [68]. Rapala et al. [69] compared the suitability of ELISA and HPLC to detect different toxin variants using several matrices (pure toxins, laboratory cultures, water and bloom samples of toxic cyanobacteria). Despite the possible overestimation of toxin concentrations with HPLC in standard toxins, the analyses of the field samples gave lower values than ELISA assay. This was at least partly due to the concentrating necessary of HPLC samples and the extra purification step by SPE (or ICA) to eliminate impurities while the samples for the ELISA test were analysed directly.

It is possible that both techniques (HPLC and ELISA) could produce different results on unknown samples not because of poor performance characteristics, but due to the fact that they measure different things [68]. Immunoassays have considerable potential for cyanobacterial toxins analysis in terms of sensitivity, specificity and convenience, but have a potential for false positive reactions [70]. One limitation of the HPLC-DAD and HPLC-MS/MS method is that they are best suited to detecting MCs for which analytical standards are available $[68,69]$. In this study the ELISA 
assay was used as screening test and the results obtained by HPLC-UV are the most reliable, giving information about the identity of individual toxins existing in natural samples. In fact, ELISAs can be useful tools for the screening of waters and cyanobacterial blooms for MCs and nodularins, although users should be aware that commercial kits can be susceptible to interference by commonly encountered environmental and laboratory conditions and materials [40].

\section{References}

[1] H. Park, M.F. Watanabe. In Toxic Microcystis, M.F. Watanabe, K.-H. Harada, W.W. Carmichael, H. Fujiki (Eds), pp. 57-77, CRC Press, Boca Ratón (1996).

[2] G.A. Codd, C.J. Ward, K.A. Beattie, S.G. Bell. In The Phototrophic Prokariotes, G.A. Peschek, W. Loffelhardt, G. Schmetterer (Eds), pp. 623-632, Kluwer Academic/Plenum Publishers, New York (1999).

[3] I. Chorus, J. Bartram. Toxic Cyanobacteria in Water, E. \& FN Spoon and WHO, Geneva (1999).

[4] J. Fastner, U. Neumann, B. Wirsing, J. Weckesser, C. Wiedner, B. Nixdorf, I. Chorus. Environ. Toxicol., 14, 13 (1999).

[5] F. Pomati, S. Sacchi, C. Rossetti, S. Giovannardi, H. Onodera, Y. Oshima, B.A. Neilan. J. Phycol., 36, $553(2000)$.

[6] J.F. Blom, J.A. Robinson, F. Jüttner. Toxicon, 39, 1923 (2001).

[7] M. Tarczyinska, Z. Romanowska-Duda, T. Jurczak, M. Zalewski. Water Sci. and Technology: Water Supply, 1, 237 (2001).

[8] P. Domingos, T.K. Rubim, R.J.R. Molica, S.M.F.O. Zevedo, W.W. Carmichael. Environ. Toxicol., 14, 31 (1999).

[9] K. Sivonen. Phycologia, 35, 12 (1996).

[10] P. Pereira, H. Onodera, D. Andrinolo, S. Franca, F. Araújo, N. Lagos, Y. Oshima, Toxicon, 38, 1689 (2000).

[11] F.M.B. Ferreira, J. Franco, J.M. Soler, M.L. Fidalgo, P. Fernandez-Vila. Toxicon, 39, 757 (2001).

[12] K. Sivonen, G. Jones. In Toxic Cyanobacteria in Water. A Guide to their Public Health Consequences, Monitoring and Management, I. Chorus, J. Bartram (Eds), pp. 41-111, E \& FN Spon, New York (1999).

[13] L. Spoof, P. Vesterkvist, T. Lindholm, J. Meriluoto. J. Chromatogr. A, 1020, 105 (2003).

[14] H. Park, C. Iwami, M. Watanabe, K.-I. Harada, T. Okino, H. Hayashi. Environ. Toxicol. Wat. Qual., 13, 61 (1998).

[15] W.W. Carmichael. In Manual on Harmful Marine Microalgae, G.M. Hallegraeff, D.M. Anderson, A.D. Cembella (Eds), pp. 163-175, IOC Manuals and Guides no. 33, UNESCO (1995).

[16] E.M. Jochimsen, W.W. Carmichael, J. An, D.M. Cardo, S.T. Cookson, C.E.M. Holmes, B.C. Antunes, D.A.M. Liho, T.M. Lyra, V.S.T. Barreto, S.M.F.O. Azevedo, W.R. Jarvis. The NEJM, 338, 873 (1998).

[17] I.R. Falconer. Environ. Toxicol., 14, 5 (1999).

[18] I.R. Falconer, M.D. Burch, D.A. Steffensen, M. Choice, O.R. Coverdale. Environ. Toxicol. Wat. Qual., 9, 131 (1994).

[19] S.G. Bell, G.A. Codd. Rev. Med. Microbiol., 5, 256 (1994).

[20] M. Runnegar, N. Berdt, S.-M. Kong, E.Y.C. Lee, L. Zhang, Biochem, Biophys. Res. Commun., 216, 162 (1995).

[21] R. Nishiwaki-Matsushima, T. Ohta, S. Nishiwaki, M. Sugawama, K. Kohyama, T. Ishikawa, W.W. Carmichael, H. Fujiki. J. Cancer Res. Clin. Oncol., 118, 420 (1992).

[22] W.-X. Ding, H.-M. Shen, H.-G. Zhu, B.-L. Lee, C.-N. Ong. Mutat. Res., 442, 69 (1999).

[23] S.Z. Yu. J. Gastroenterol. Hepatol., 10, 674 (1995).

[24] Y. Ueno, S. Nagata, T. Tsutsumi, A. Hasegawa, F. Yoshida, M. Suttajit, D. Mebs, M. Pütsch, V. Vasconcelos. Nat. Toxins, 4, 271 (1996).

[25] V.M. Vasconcelos. Verb. Internat. Verein. Limnol., 25, 694 (1993).

[26] V.M. Vasconcelos, K. Sivonen, W.R. Evans, W.W. Carmichael, M. Namikoshi. Water Res., 30, 2377 (1996).

[27] V.M. Vasconcelos. Braz. J. Med. Biol. Res., 32, 249 (1999).

[28] C. Rocha, H. Galvao, A. Barbosa. Marine Ecology Progress Series, 228, 35 (2002).

[29] A.K.M. Kabzinski, R. Juszczak, E. Miekos, M. Tarczynska, K. Sivonen, J. Rapala. Polish J. Environ. Studies, 9, 171 (2000).

[30] I. Moreno, A. Cameán, M.J. Tavares, P. Pereira, S. Franca. Aquatic Ecosystem and Health Management, 6, 409 (2003).

[31] I. Moreno, P. Pereira, S. Franca, A. Cameán. Biol. Res., 37, 405 (2004).

[32] C.F.B. Holmes. Toxicon, 29, 469 (1991). 
[33] J. An, W.W. Carmichael. Toxicon, 32, 1495 (1994).

[34] F.S. Chu, X. Huang, R.D. Wei. J. AOAC Intern., 73, 451 (1990).

[35] M. Barco, J. Rivera, J. Caixach. J. Chromatogr. A, 959, 103 (2002).

[36] L. Zhang, X. Ping, Z. Yang. Talanta, 62, 193 (2004).

[37] E.C. Aguete, A. Gago-Martinez, J.A. Rodriguez-Vazquez, S. O’Connel, C. Moroney, K.J. James. Chromatographia, 53, 254 (2001).

[38] E.C. Aguete, A. Gago-Martinez, J.M. Leao, J.A. Rodriguez-Vazquez, C. Menard, J.F. Lawrence. Talanta, 59, 697 (2003).

[39] J.F. Lawrence, C. Menard. J. Chromatogr. A, 922, 111 (2001).

[40] J.S. Metcalf, P. Hyenstrand, K.A. Beattie, G.A. Codd. J. Appl. Microbiol., 89, 532 (2000).

[41] H. Utermöhl. Mitt. Int. Verein. Theor. Angew. Limnol., 5, 567 (1958).

[42] American Public Health Association (APHA), American Water Works Association (AWWA), Water Environment Federation (WEF). In Standard Methods for the Examination of Water and Wastewater, M.A.H. Franson (Ed.), pp. 10.18-10.22, APHA, Baltimore (1998).

[43] T. Lanaras, S. Tsitsamis, C. Chlichlia, C.M. Cook. J. Appl. Phycol., 1, 67 (1989).

[44] H. Park, M.F. Watanabe, K.-I. Harada, H. Nagai, M. Suzuki, M. Watanabe, H. Hayashi. Nat. Toxins, 1, 353 (1993).

[45] K. Tsuji, S. Setsuda, T. Watanuki, F. Kondo, H. Nakazaa, M. Suzuki, K.-I. Harada. Nat. Toxins, 4, 189 (1996).

[46] J.S. Yunes, A. Matthiensen, M. Paris, P.S. Salomon, S.L. Ragget, K.A. Beattie, G.A. Codd. In T. Harmful Algae, B. Reguera, J. Blanco, M.L. Fernandez, T. Wyatt (Eds), pp. 18-21, Xunta de Galicia and Intergovernmental Oceanographic Commission of UNESCO, Galicia (1998).

[47] P. Pereira, M.J. Tavares, V. Vasconcelos, S. Franca. VI Reunión Ibérica sobre fitoplancton tóxico y biotoxinas. Abstract book, 109-117 (1999).

[48] B. Sedmark, G. Kosi. Nat. Toxins, 5, 64 (1997).

[49] B. Sedmark, G. Kosi. J. Plankton Res., 20, 691 (1998).

[50] Organization for Economic Cooperation and Development. Eutrophication of Waters: Monitoring, Assessment and Control, Organization for Economic Cooperation and Development, Paris, France (1982).

[51] J. Bartram, W.W. Carmichael, I. Chorus, G. Jones, O. Skulberg. In Toxic Cyanobacteria in Water. A Guide to their Public Health Consequences, Monitoring and Management, I. Chorus, J. Bartram (Eds), pp. 1-14, E \& FN Spon, New York (1999).

[52] B.G. Kotak, R.W. Zurawell, E.E. Prepas, C.F.B. Holmes. Can. J. Fisheries Aquat. Sci., 53, 1974 (1996).

[53] G.A. Codd. In Harmful Algae, B. Reguera, J. Blanco, M.L. Fernandez, T. Wyatt (Eds), pp. 13-17, Xunta de Galicia and Intergovernmental Oceanographic Commission of UNESCO, Galicia (1998).

[54] H.-M. Oh, S.J. Lee, J.-H. Kim, H.-S. Kim, B.-D. Yoon. Appl. Environ. Microbiol., 67, 1484 (2001).

[55] F. Kondo, Y. Ito, H. Oka, S. Yamada, K. Tsuji, M. Imokawa, Y. Niimi, K.-I. Harada, Y. Ueno, Y. Miyazaki. Toxicon, 40, 893 (2002).

[56] T. Jurczak, M. Tarczyñska, K. Karlson, J. Meriluoto, Chromatographia, 59, 571 (2004).

[57] K. Lahti, J. Rapala, M. Färdig, M. Niemelä, K. Sivonen. Wat. Res., 31, 1005 (1997).

[58] H. Park, M.F. Watanabe, K. Harada, M. Suzuki, H. Hayashi, T. Okino, Environ. Toxicol. Wat. Qual., 8, 425 (1993).

[59] D. Jungmann, J. Benndorf. Freshwater Biol., 32, 13 (1994).

[60] J. Fastner, M. Erhard, W.W. Carmichael, F. Sun, K.L. Rinehart, H. Rönicke, I. Chorus. Arch. Hydrobiol., 145, 147 (1999).

[61] P. Henriksen, Phycologia, 35, 102 (1996).

[62] B. Marsalek, L. Blaha, F. Hindak. Biologia, 55, 645 (2000).

[63] M.F. Watanabe, K. Harada, K. Matsuura, S. Oishi, Y. Watanabe, M. Suzuki. Toxicity Asses., 4, 487 (1989).

[64] M. Shirai, A. Ohtake, T. Sano, S. Matsumoto, T. Sakamoto, A. Sato, T. Aida, K. Harada, T. Shimada, M. Suzuki, M. Nakano. Appl. Environ. Microbiol., 57, 1241 (1991).

[65] M.F. Watanabe. In Toxic Microcystis, M.F. Watanabe, K. Harada, W.W. Carmichael, H. Fujiki (Eds), pp. 35-56, CRC Press, Boca Raton (1996).

[66] R. Luukkainen, M. Namikoshi, K. Sivonen, K. Rinehart, S.I. Niemelä. Toxicon, 32, 133 (1994).

[67] M. Barco, C. Flores, J. Rivera, J. Caixach. Toxicon, 44, 881 (2004).

[68] J.F. Lawrence, B. Niedzwiadek, C. Menard, B.P.Y. Lau, T. Kuiper-Goodaman. J. AOAC Intern., 84, 1035 (2001).

[69] J. Rapala, K. Erkomaa, J. Kukkonen, K. Sivonen, K. Lahti. Anal. Chim. Acta, 466, 213 (2002).

[70] T. Flury, R. Heinze, B. Wirsing, J. Fastner, U. Neumann, J. Weckesser. Cyanotoxins, 356, 330 (2001). 